\title{
THE ROLE OF VITAMIN D SUPPLEMENTATION FOR HEAD AND NECK CANCER : A LITERATURE REVIEW
}

Dewi Kania Intan Permatasari ${ }^{*}$ Irna Sufiawati ${ }^{* *}$

\section{Keywords:} head and neck cancer, quality of life, recurrence, vitamin $D$

\section{ABSTRACT}

Background: Vitamin D has several roles, namely physiological function of calcium and bone metabolism, cell growth and differentiation, immune and cardiovascular function. Vitamin D deficiency can cause the risk of cancer. Head and neck cancer is one of the cancers that occur due to vitamin D deficiency in the body. This literature review was to asses and evaluate the impact and benefits of vitamin $D$ supplementation for head and neck cancer.

Discussion: A study found an association between vitamin $D$ supplementation and a low risk of recurrence in conditions of high total vitamin $D$ levels. Another study found a significant increase in quality of life (QOL). The primary mechanism of vitamin $\mathrm{D}$ action is mediated through binding of either 1,25(OH)2D3 (active form) or $25(\mathrm{OH}) \mathrm{D}$ (less active form) to the VDR, which is a member of the nuclear receptor superfamily of steroid and thyroid hormones with gene-regulatory and consequent anti-proliferative properties.

Conclusions: Vitamin D supplementation provides a role in improving the condition of patients with head and neck cancer. Both in terms of suppressing recurrence and in terms of increasing quality of life.

\section{INTRODUCTION}

Vitamin $D$ is a steroid hormone, consisting of cholecalciferol (vitamin $D_{3}$ ) which is an endogenous form and synthesized in the skin by the action of ultraviolet light, and ergocalciferol (vitamin $D_{2}$ ) which is an exogenous form and is obtained through consumption of food or supplements ${ }^{1-4}$. In the liver and other tissues ergocalciferol and cholecalciferol are converted to $25(\mathrm{OH}) \mathrm{D}$. Then $25(\mathrm{OH}) \mathrm{D}$ is metabolized to its active form 1,25 dihydroxyvitamin $\mathrm{D}$ $\left[1,25(\mathrm{OH})_{2} \mathrm{D}\right]$ by 25 -hydroxyvitamin D-1-a-hydroxylase, or CYP27B1. This hydroxylation occurs mainly in the kidneys, but extra kidney tissue and immune cells are also capable of producing $1,25(\mathrm{OH})_{2} \mathrm{D}$. The active form of Vitamin $D(1,25$-dihydroxyvitamin $D)$ is a powerful immunomodulator with receptors in macrophages, monocytes $\mathrm{T}$ and $\mathrm{B}$ lymphocytes ${ }^{5-8}$.
To determine vitamin $D$ status Serum $25(\mathrm{OH}) \mathrm{D}$ was used, although the cut off value for classifying insufficiency/deficiency was inconsistent. However, a general definition for vitamin $D$ status based on serum levels of 25(OH)D has been widely established and adopted: Deficiency $<20 \mathrm{ng} / \mathrm{ml}(50 \mathrm{nmol} / \mathrm{l})$; insufficient $21-29 \mathrm{ng} / \mathrm{ml}(52-72 \mathrm{nmol} / \mathrm{l})$; enough > $30 \mathrm{ng} / \mathrm{ml}(>75 \mathrm{nmol} / \mathrm{l})$ 4,9. According to The National Academy of Sciences recommends the following daily intakes of vitamin $D: 1$ to 50 years, $5 \mu \mathrm{g}$ (200 IU); 51-70 years, $10 \mu \mathrm{g}$ (400 $\mathrm{IU})$ is older than 71 years $15 \mu \mathrm{g}$ (600 IU). In one study, 12,5 $\mu \mathrm{g}$ (500 IU) per day was associated with $30 \mathrm{ng} / \mathrm{mL} 25(\mathrm{OH}) \mathrm{D}$ levels ${ }^{10}$.

Vitamin $D$ has many functions in terms of suppressing cancer through its various effects as antitumor, antiproliferative, apoptosis and angiogenesis. Therefore, individuals with low serum vitamin $D$ levels will have a high risk of

${ }^{*}$ Oral Medicine Specialist Program, Faculty of Dentistry, Universitas Padjadjaran, Dr. Hasan Sadikin Hospital, Bandung-Indonesia, **Oral Medicine Department, Faculty of Dentistry, Universitas Padjadjaran, Dr. Hasan Sadikin Hospital, Bandung-Indonesia

Korespondensi: dewi.kania.ip@gmail.com 
developing cancer. Head and neck cancers including oral cancer have a low response to chemotherapy and anti-cancer drugs. Therefore, it is very possible for resistance to chemotherapy and radiotherapy. Vitamin $D$ is expected to provide a better response to cancer therapy and prevent recurrence ${ }^{2,11-18}$.

Some studies show that vitamin D can play an important role in the incidence of cancer. It is estimated that vitamin $D$ acts through vitamin $\mathrm{D}$ receptors (VDR) to produce anti-cancer effects and has the potential to regulate immune cells. This known transcription phenomenon is responsive to binding to vitamin $D$, expressed in many normal and malignant tissues, binds to target genes that regulate cell growth, and has been shown to be removed or lowered regulated in tumor tissue. Preclinical studies of the biologically active forms of vitamin $\mathrm{D}, 1,25(\mathrm{OH})_{2} \mathrm{D}$ also support vitamin D-mediated antiproliferation and induce apoptosis of cancer cells ${ }^{19,20}$.

To assess and determine the efficacy of vitamin D supplementation in the treatment of head and neck cancer in terms of reducing the risk of recurrence and improving quality of life.

\section{LITERATURE REVIEW}

Literature search was performed in PubMed and Google Scholar databases between January 2008 until September 2018. The following keywords were used in the search "vitamin D and oral cancer" or "vitamin D head and neck cancer". Titles and abstract of each publication were repeatedly reviewed in the search process. The entire article was checked when necessary. To avoid any possible reports missed in the literature search, we reviewed references from relevant articles and related reviews to identify potensial relevant studies.

The inclusion criteria will be used for selecting articles as follows :

- English and Indonesian language articles published between January 2008 until September 2018

- Study type cohort study and randomized controlled trials (RCTs) with any dose or formulation of vitamin $\mathrm{D}$ intervention compared with placebo or no treatment

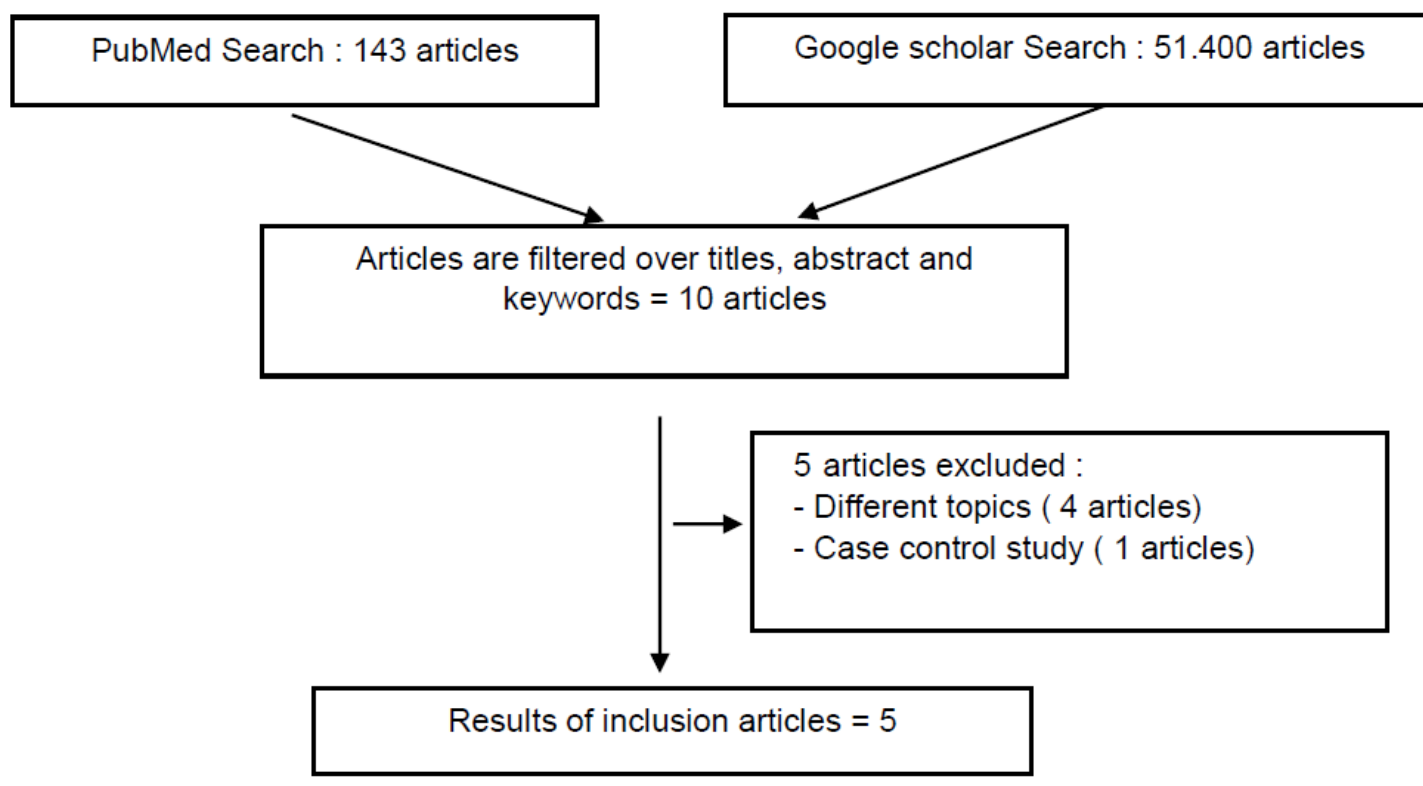

Figure 1 Flowchart of Study Selection 
- Head and neck cancer based on requrrance and quality of life

Data extraction sumarized in 4 tables. There were two outcome measures we used in order to know the role of supplementation vitamin $D$ in included studies. The first outcome was the requrrance of cancer and the second outcome was of quality of life.

Number of 51.543 articles we got from PubMed and Google scholar, we filter articles based on title, abstract and keywords to find 10 articles, then we read 10 articles in full text, 5 articles do not enter criteria, namely 4 articles not included in the title and 1 case study arti-

Tabel 1. Study Characteristic

\begin{tabular}{|c|c|c|c|c|c|c|}
\hline No. & $\begin{array}{c}\text { Publication } \\
\text { Year }\end{array}$ & Author & Title & Design Study & Area & Cancer \\
\hline 1 & 2009 & $\begin{array}{l}\text { Lyel } \\
\text { Roh,Jong. } \\
\text { et.al. }{ }^{21}\end{array}$ & $\begin{array}{l}\text { Prevention of Post Operative } \\
\text { Hypocalcemia With Routine Oral } \\
\text { Calcium and Vitamin D } \\
\text { Supplements in Patiens With } \\
\text { Differentiated Papillary Thyroid } \\
\text { Carcinoma Undergoing Total } \\
\text { Thyroidectomy Plus Central Neck } \\
\text { Dissection }\end{array}$ & $\begin{array}{l}\text { Randomized } \\
\text { Control Study }\end{array}$ & $\begin{array}{l}\text { Republic } \\
\text { of Korea }\end{array}$ & $\begin{array}{l}\text { Papillary } \\
\text { Thyroid } \\
\text { Carcinoma }\end{array}$ \\
\hline 2 & 2010 & $\begin{array}{l}\text { Walsh, } \\
\text { Jarrett } \\
\text { E.et.al. }{ }^{22}\end{array}$ & $\begin{array}{l}\text { Use of } a, 25 \text {-Dihydroxy Vitamin D } \\
\text { Treatment to Stimulate Immune } \\
\text { Infiltration Into Head and Neck } \\
\text { Squamous Cell Carcinoma }\end{array}$ & $\begin{array}{l}\text { Randomized } \\
\text { trial }\end{array}$ & USA & HNSCC \\
\hline 3 & 2016 & $\begin{array}{l}\text { Wang, } \\
\text { Lu.et.al. }{ }^{23}\end{array}$ & $\begin{array}{l}\text { Longitudinal, Observational Study } \\
\text { on Associations Between } \\
\text { Postoperative Nutritional Vitamin D } \\
\text { Supplementation and Clinical } \\
\text { Outcomes in Esophageal Cancer } \\
\text { Patients Undergoing } \\
\text { Esophagectomy }\end{array}$ & $\begin{array}{l}\text { Longitudinal } \\
\text { observational } \\
\text { study }\end{array}$ & China & $\begin{array}{c}\text { Esophageal } \\
\text { Cancer }\end{array}$ \\
\hline 4 & 2017 & $\begin{array}{l}\text { Anand, } \\
\text { Akshay.et. } \\
\text { al. }^{11}\end{array}$ & $\begin{array}{l}\text { Expression of Vitamin D Receptor } \\
\text { and Vitamin D Status in Patients } \\
\text { with Oral Neoplasm and Effect of } \\
\text { Supplementation on Vitamin D } \\
\text { Quality of Live in Advanced } \\
\text { Cancer Treatment }\end{array}$ & $\begin{array}{l}\text { Prospective } \\
\text { Observational } \\
\text { Study }\end{array}$ & India & oscc \\
\hline 5 & 2018 & $\begin{array}{l}\text { Yokosawa, } \\
\text { Eva B. } \\
\text { et.al. }{ }^{19}\end{array}$ & $\begin{array}{l}\text { Vitamin D Intake and Survival and } \\
\text { Recurrence in Head and Neck } \\
\text { Cancer Patients }\end{array}$ & $\begin{array}{l}\text { Prospective } \\
\text { cohort study }\end{array}$ & USA & $\mathrm{HNC}$ \\
\hline
\end{tabular}

Tabel 2. Sample Characteristic

\begin{tabular}{cclccc}
\hline NO. & Publication Year & \multicolumn{1}{c}{ Author } & Age (year) & Subject & Sex (M/F) \\
\hline 1 & 2009 & Lyel Roh,Jong.et.al. ${ }^{21}$ & $22-77$ & 49 & $9 / 40$ \\
2 & 2010 & Walsh, Jarrett E.et.al. ${ }^{22}$ & $45-92$ & 16 & $9 / 7$ \\
3 & 2016 & Wang, Lu.et.al. $^{23}$ & Mean Age 61 & 49 & $40 / 9$ \\
4 & 2017 & Anand, Akshay, et al. $^{11}$ & Mean Age 42 & 24 & N/A \\
5 & 2018 & Yokosawa, Eva B. $^{2}$ & Mean Age & 434 & $434 /-$ \\
\hline
\end{tabular}


cle. Therefore, the author gets 5 articles that match the inclusion criteria.

The 5 articles that the research design obtained, the following were two RCT (Randomized Control Study) designs and three Cohort research designs (longitudinal observational studies, prospective observational studies, and prospective cohort studies). The type of head and neck cancer that occurs is papillary thyroid carcinoma, head and neck squamous carcinoma, esophageal cancer, oral squamous cell carcinoma and head and neck cancer (Table 1). The articles was published in 2009 until 2018. Total sample 572 peoples, with male gender as many as 492 people and women as many as 56 people for 4 articles because 1 article does not explain about gender. The sam- ple age range is 22-92 years (Table 2).

Supplementation of vitamin $D$ varies as low as $1 \mu \mathrm{g}$ per day and the largest is $25 \mu \mathrm{g}$ per day. The outcome of reducing recurrence can be seen in 3 authors, Yokosawa, Eva B. et.al. ${ }^{19}$, Lyel oh, Jong.et.al. ${ }^{21}$, Walsh, Jarrett E.et.al. ${ }^{22}$ and the outcome of improving quality of life can be seen from 3 authors namely Anand, Akshay, et al. ${ }^{11}$, Lyel Roh, Jong.et.al. ${ }^{21}$ and Wang, Lu.et.al. ${ }^{23}$ (Table 3 and Table 4).

Yokosawa, Eva B, et al. found that recurrence occurred in $9.2 \%$ of patients who received vitamin $\mathrm{D}$ supplementation of more than $16.875 \mu \mathrm{g}$ per day and $12.96 \%$ of recurrences occurred at vitamin $D$ supplementation of less than $5 \mu \mathrm{g}$ per day ${ }^{19}$ (Tabel 3).

Tabel 3. Supplementation Dose and Recurrance Risk Outcome

\begin{tabular}{|c|c|c|c|}
\hline No. & Author & $\begin{array}{c}\text { Supplementation Vitamin D per } \\
\text { oral (Dose) }\end{array}$ & Recurrence \\
\hline 1 & Yokosawa, Eva B. et.al. ${ }^{19}$ & $<5-\geq 16,875 \mu \mathrm{g}$ & $\begin{array}{ll}\text { - } & \text { Recurrance was seen in } 9.2 \% \\
\text { patient with } \geq 16,875 \mu \mathrm{g} \\
\text { supplementation vitamin } \mathrm{D} \\
\text { - } \quad 14,7 \% \text { patient with } 11,625 \mu \mathrm{g} \text { - } \leq \\
\quad 16,875 \mu \mathrm{g} \\
\text { - } \quad 17,6 \% \text { with } 5 \mu \mathrm{g}-\leq 11.625 \mu \mathrm{g} \\
\text { - } \quad 12.96 \% \text { with } \leq 5 \mu \mathrm{g} \\
\text { supplementation with vitamin D }\end{array}$ \\
\hline 2 & Lyel Roh,Jong.et.al. ${ }^{21}$ & $\begin{array}{l}\text { Calcium } 3 \mathrm{~g} / \text { Day and vitamin D } 1 \\
\mu \mathrm{g} / \text { Day } \\
\text { (administered as } 0,5 \mu \mathrm{g} \text { twice daily) }\end{array}$ & $\begin{array}{l}\text { Reccurence developed in the lateral } \\
\text { neck }(0,5 \%)\end{array}$ \\
\hline 3 & Walsh, Jarrett E.et.al. ${ }^{22}$ & $4 \mu \mathrm{g} / \mathrm{Day}$ & $\begin{array}{l}\text { Patient group who received vitamin } D \\
\text { treatment had a longer time to } \\
\text { recurrence than no treatment. }\end{array}$ \\
\hline
\end{tabular}

Tabel 4. Supplementation Dose and Quality of Life Outcome

\begin{tabular}{|c|c|c|c|}
\hline No. & Author & $\begin{array}{l}\text { Supplementation vitamin D per oral } \\
\text { (Dose) }\end{array}$ & Quality of life \\
\hline 1 & $\begin{array}{l}\text { Anand, Akshay, et al. } \\
11\end{array}$ & Vitamin D $25 \mu g /$ Day & $\begin{array}{l}\text { Quality of Life improved with } \\
\text { supplementation Vitamin D }\end{array}$ \\
\hline 2 & Lyel Roh,Jong.et.al. ${ }^{21}$ & $\begin{array}{l}\text { Calcium } 3 \mathrm{~g} / \text { Day and vitamin D } 1 \\
\mu \mathrm{g} / \text { Day } \\
\text { (administered as } 0,5 \mu \mathrm{g} \text { twice daily) }\end{array}$ & $\begin{array}{l}\text { Hypocalcemia symptoms were } \\
\text { minimal in supplementation calcium } \\
\text { and vitamin } D\end{array}$ \\
\hline 3 & Wang, Lu.et.al. ${ }^{23}$ & $5-10 \mu g / D a y$ & $\begin{array}{l}\text { Vitamin D supplementation had higher } \\
\text { scores of physical functioning, social } \\
\text { functioning, and global health }\end{array}$ \\
\hline
\end{tabular}




\section{DISCUSSION}

Geographical variation is very important in terms of mortality in cancer, which is associated with latitude and ultraviolet- $B$ radiation in the sun. Photosynthesis of vitamin $D_{3}$ (cholecalsiferol) occurs in the skin by the action of ultraviolet-B radiation in the sun. Overall vitamin $D$ status in a person depends on cholecalciferol and ergocalciferol (Vitamin $D_{2}$ ). 25-Dyhydroxyvitamin $D$, is a major form of circulation of vitamin $D$, reflecting the cumulative effect of sun exposure and dietary intake of vitamin $D$ $1-4,24,25$

The primary mechanism of vitamin D action is mediated through binding of either $1,25(\mathrm{OH})_{2} \mathrm{D}_{3}$ (active form) or $25(\mathrm{OH}) \mathrm{D}$ (less active form) to the VDR, which is a member of the nuclear receptor superfamily of steroid and thyroid hormones with gene-regulatory and consequent anti-proliferative properties ${ }^{2}$. Binding of $1,25(\mathrm{OH})_{2} \mathrm{D}$ to the VDR (either in the cell nucleus or in the cytoplasm) promotes association of the VDR-1,25(OH) ${ }_{2} \mathrm{D}$ complex with the retinoid $X$ receptor $(R X R)^{2}$. The 1,25(OH) $)_{2} \mathrm{D}-\mathrm{VDR}-\mathrm{RXR}$ complex binds to vitamin D-response elements in DNA which operate to initiate gene transcription. Activation of the VDR by $1,25(\mathrm{OH})_{2} \mathrm{D}$ can restore or enhance proapoptotic effects in different cancer cells through transcriptional activation of bax and p-calpain, two effective proapoptotic proteins. VDR-vitamin D activation also been demonstrated to increase mRNA expression of transforming growth factor, a potent antiproliferative cytokine in normal and early stage cancer cells; superoxide dismutase, which may reduce oxidative stress-induced DNA damage and loss to DNA repair mechanisms that contribute to carcinogenesis and inflammatory cytokine production; as well as cyclin-dependent kinase (CDK) inhibitor p21, RBL2, RBLP6 and forkhead box O (FOXO) tumour suppressors that function to counteract MAPK-mediated phosphorylation and growth ${ }^{2}$. VDR activation may also facilitate transcriptional repression of Bc1-2 and telomerase (pro-survival proteins), as well as CDK1 mRNA, which encodes a required protein for cellcycle progression. Suppression of vascular endothelial growth factor, responsible for angiogenesis, as well as the pro-inflammatory cyclooxygenase-2, was also observed. In addition, 1,25(OH)2D may disrupt the function of $\beta$-catenin, the terminal mediator of Wnt signalling, which activates transcription of genes whose protein products (c-Myc and cyclin D1) control cell proliferation, as well as insulin-like growth factor-stimulated tumour growth².

A study found an association between vitamin $D$ supplementation and a low risk of recurrence in conditions of high total vitamin D levels ${ }^{19}$. Another study found a significant increase in quality of life (QOL) and Disease-Free Survival (DFS) in esophageal cancer (EC) patients who underwent esophagectomy who received vitamin D supplementation during cancer treatment and post recovery ${ }^{23}$. T-cell functional competence is very important to stimulate antitumor immune reactivity. However, patients with head and neck squamous cell carcinoma have low immunity. There are several immune inhibitory mechanisms mediated by HNSCC (Head and Neck Squamous Cell Carcinoma), including the induction of their immune suppressing cells that block the host's immune reactivity. This study shows that treatment of patients with advanced HNSCC disease with vitamin D supplementation reduces the level of immune inhibitory CD34 cells in peripheral blood and simultaneously increases peripheral blood cell immune reactivi- 
$t^{22}$. Likewise, prior study said that low vitamin $\mathrm{D}$ levels are closely related to the risk of neck and head cancer, then he said that vitamin D supplementation significantly improved healing of erythema, lichenoid, edema, ulceration and pain in patient oral cancer ${ }^{11}$.

There are many benefits of vitamin $D$ for body health. Therefore, we must always keep vitamin $\mathrm{D}$ levels in the body in sufficient condition. In addition to providing preventive benefits in the prevention of infections, cardiovascular disorders, and cancer ${ }^{26}$. Vitamin D supplementation provides curative benefits in cancer patients in terms of suppressing the cancer itself, preventing recurrence and improving quality of life ${ }^{11,19,21-23}$.

\section{CONCLUSION}

Vitamin D supplementation provides a role in improving the condition of patients with head and neck cancer. Both in terms of suppressing recurrence and in terms of increasing quality of life. But unfortunately there is still few research on vitamin $D$ supplementation on oral cancer or head and neck cancer, therefore more researchers are expected to conduct research related to the role of vitamin $\mathrm{D}$, especially in terms of oral cavity health.

\section{REFERENCES}

1. Lips PÃ. Vitamin D physiology. 2006;92:4-8. doi:10.1016/j.pbiomolbio.2006.02.016

2. Oa L, London P, Commons C, License A. Kingsley K , Bergman C , Keiserman M , Mobley C . Oral cancer risk and vitamin D status, intake, and supplementation : A review . OA. 2013;1(1).

3. Maria S, Ferreira S, Henrique M, et al. Prevalence of hypovitaminosis $D$ and its association with oral lesions in HIV-infected Brazilian adults. Rev Soc Bras Med Trop. 2016;49(1):90-94.

4. Orkin C, Wohl DA, Williams A, Deckx H. Vitamin D Deficiency in HIV : A Shadow on Long-Term Management ? AIDS Rev. 2014:59-74.

5. Tsiaras WG, Weinstock MA. Factors Influenc- ing Vitamin D Status. 2011;25(2):115-124. doi:10.2340/00015555-0980

6. Lopiccolo MC, Lim HW. Vitamin D in health and disease. 2010;2:224-229.

7. Lake J, Adam J. Vitamin D in HIV-Infected Patients. NIH Public Access. 2011;8(3):133-141. doi:10.1007/s11904-011-0082-8.Vitamin

8. Feldman BJ. The role of vitamin $D$ in reducing cancer risk and progression. Nat Publ Gr. 2014;14(5):342-358. doi:10.1038/nrc3691

9. Vashi PG, Trukova K, Lammersfeld CA, Braun DP, Gupta D. Impact of oral vitamin D supplementation on serum 25-hydroxyvitamin $D$ levels in oncology. Nutr J. 2010;9(1):60. doi:10.1186/1475-2891-9-60

10. Garland CF, Garland FC, Gorham ED, et al. The Role of Vitamin D in Cancer Prevention. 2006;96(2):252-261. doi:10.2105/ AJPH.2004.045260

11. Anand A, Singh S, Sonkar AA, Husain N. Expression of vitamin $D$ receptor and vitamin $D$ status in patients with oral neoplasms and effect of vitamin $D$ supplementation on quality of life in advanced cancer treatment. Contemp Oncol. 2017;21(2):145-151.

12. Grimm $M$, Cetindis $M$, Biegner $T$, Lehman $M$, Munz A, Teriete P. Serum vitamin D levels of patients with oral squamous cell carcinoma ( OSCC ) and expression of vitamin $D$ receptor in oral precancerous lesions and OSCC. 2015;20(2). doi:10.4317/medoral.20368

13. Zeljic K, Supic G, Radak MS, Jovic N, Kozomara R. Vitamin D receptor, CYP27B1 and CYP24A1 genes polymorphisms association with oral cancer risk and survival. 2012. doi:10.1111/j.16000714.2012.01164.x

14. Tran HUY, Pant R, Adams JS, Mallya SM. Vitamin $D$ signaling regulates oral keratinocyte proliferation in vitro and in vivo. 2014;(11):1625-1633. doi:10.3892/ijo.2014.2338

15. Sundaram K, Sambandam Y. 1 a, 25-Dihydroxyvitamin D3 Modulates CYP2R1 Gene Expression in Human Oral Squamous Cell Carcinoma Tumor Cells. 2014;3. doi:10.1007/s12672-014-0170-5

16. Trump, Donald L, Deeb, Kristen, Johnson CS. Vitamin d: Considerations in the Continued Development as an Agent for Cancer Prevention and Therapy. 2010:1-9.

17. Adeyemi OM, Agniel D, French AL, et al. Vitamin D Deficiency in HIV-Infected and HIV-Uninfected Women in the United States. Jaids-Journal Acquir Immune Defic Syndr. 2011;57(3):197-204. doi:10.1097/QAI.0b013e31821ae418

18. Kotikangas HO, Schwab U, Pia O. High Prevalence of Vitamin D Insufficiency in Patients with Head and Neck Cancer at Diagnosis. 2012:1-7. doi:10.1002/hed

19. Yokosawa EB, Arthur AE, Rentschler KM, Wolf GT, Rozek LS, Mondul AM. Vitamin D Intake and Survival and Recurrence in Head and Neck Cancer Patients. 2018;25:1-6. doi:10.1002/lary.27256

20. Fleet JC. Molecular Actions of Vitamin D Con- 
tributing to Cancer Prevention. Mol Asp Med. 2008;29(6):388-396. doi:10.1016/j. mam.2008.07.003.Molecular

21. Roh J, Park J, Park C II. Prevention of Postoperative Hypocalcemia With Routine Oral Calcium and Vitamin d Supplements in Patients With Differentiated Papillary Thyroid Carcinoma Undergoing Total Thyroidectomy Plus Central Neck Dissection. 2009. doi:10.1002/cncr.24027

22. Walsh, Jarret E et al. Use of Alpha, 25 Dihydroxyvitamin D3 Treatment to Stimulate Immune Infiltration Into Head and Neck Squamous Cell Carcinoma. Hum Immunol. 2010;71(7):659-665. doi:10.1016/j.humimm.2010.04.008.Use

23. Wang L, Wang C, Wang J, Huang X, Cheng Y. Longitudinal, observational study on associations between postoperative nutritional vitamin D supplementation and clinical outcomes in esophageal cancer patients undergoing esophagectomy. Nat Publ Gr. 2016;(August):1-10. doi:10.1038/srep38962
24. Xu W, Adjei A, Bairati I, Liu G, Douville P. Dietary vitamin $D$ intake and serum 25-hydroxyvitamin D level in relation to disease outcomes in head and neck cancer patients. doi:10.1002/ijc.25496

25. Lipworth L, Rossi M, Mclaughlin JK, et al. original article Dietary vitamin D and cancers of the oral cavity and esophagus. 2009:1576-1581. doi:10.1093/annonc/mdp036

26. Holick MF, Chen TC. Vitamin D defciency: a worldwide problem with health consequences. Am J Clin Nutr. 2008;87(4):1080S-6S. doi:87/4/1080S [pii] 